\section{E-GOVERNMENT POLICY AND ITS IMPLEMENTATION IN THE CZECH REPUBLIC: SELECTED SHORTCOMINGS}

\section{David Špaček ${ }^{1}$}

Masaryk University

Abstract: The paper summarizes the specifics and challenges of e-government policy, and then discusses the apparent shortcomings of policy implementation and challenges for further development in the Czech Republic. It draws attention to problems in national e-government policy and in practical policy implementation (instability of governance, low quality of evaluation, low involvement of stakeholders in project design, and public procurement issues).

Keywords: e-government, implementation, ICT, public administration, Czech Republic

DAVID ŠPAČEK - Masaryk University, Faculty of Economics and Administration,

Lipová 41a, 60200 Brno•david.spacek@econ.muni.cz

Central European Journal of Public Policy

Vol. 9 - № 1 - May 2015 - pp 78-100

ISSN 1802-4866

○ 2015 David Špaček

Licensed under Creative Commons Attribution 3.0

\section{INTRODUCTION}

E-government has been a fashionable element of practical administrative reforms and public policies as well as public administration research since the late 1990s. The OECD, for example, has repeated many times that e-government may enable better policy outcomes, higher-quality services, greater engage-

1 The paper has been elaborated within the project of the Czech Science Foundation no. P403/12/0366, "Identification and evaluation of region specific factors determining outcomes of reforms based on NPM - the case of CEE". ment with citizens and improve other key outputs. However, current literature still demonstrates the continuing validity of the sceptical opinion of Bakos and Jager from 1995 (as cited in Willcocks \& Lester, 1996) about the following ICT productivity paradox: "computers are not boosting productivity, but the fault lies not with the technology but with its management and how computer use is overseen". Most e-government projects fail as a result of poor implementation (Heeks, 2006) and insufficient attention paid to non-technical barriers in e-government prior its implementation (Nguyen, Teicher, Van Gramberg \& Tran, 2014). Although existing national organizational structures for e-government implementation are being modified in many European countries (Špaček, 2014), the criticism appearing still in the latest OECD overview on e-government (OECD, 2009) and current European e-government policy documents (European Commission, 2010a, 2010b) indicates problems of e-government implementation and evaluation.

Socio-technical in their nature, e-government systems are embedded within a broader context of people, management, public agencies, IT vendors, politics, culture etc. (Heeks, 2006). The literature on e-government implementation and evaluation clearly indicates that its approaches try to cope with specific characteristics which are different from other public policies. For example, as Kudo (2008) points out, e-government represents a specific public policy it is an overall policy, covering different economic sectors, and it deals with the policy-making process and the organization and management of government in general.

E-government represents a specific area of public policies where an interdisciplinary approach in theory and practice is inevitable, particularly because of the complexity (interdisciplinarity) of e-government with regard to its aims, preconditions and barriers. Since e-government represents an alternative to traditional administrative and governance processes, its complexity also derives from the specifics of public administration and public services themselves (e.g., the executive nature of public administration and the requirements of rule of law; the role and practice of political leadership; the multi-layered character of present governance systems, with more hierarchical and more autonomous sub-systems of state administration at the local and regional levels that are harder to coordinate from the national level; contradictory aims of public management reforms; multiple and sometimes contradictory roles of citizens; multiple stakeholders; monopolistic provision of many public services (Špaček, 2012b).

Regardless of the existing level of globalization of administrative reforms, patterns of adoption of technology and organizational change are still contextdependent to a certain degree (e.g., Wong \& Welch, 2004; Pina, Torres \& Royo, 
2010). This paper outlines an existing approach to e-government policy in the Czech Republic and deals with the question, "What features can be seen in the implementation of e-government policy?" It focuses particularly on the approach of the national level (represented by the national government, responsible ministries and other central authorities).

In order to answer the question, the paper first summarizes the specifics and challenges of e-government policy, and then discusses the apparent shortcomings of e-government policy implementation and challenges for further development in the Czech Republic. With regard to the first part of the paper, the methodology on which the paper builds is based particularly on a literature review. In order to discuss the Czech case of national e-government implementation, official government documents were studied together with stakeholder comments (including those expressed in interviews with representatives of main associations of regional and local governments and their top executives)

The paper also summarizes the main findings of the author's studies of e-government implementation practices of central, regional and local authorities in the Czech Republic.

\section{E-GOVERNMENT - CHALLENGES OF A SPECIFIC \\ CROSS-SECTORAL PUBLIC POLICY}

E-government is a rapidly growing phenomenon (Heeks, 2006) and its literature is vast. In general, the e-gov terminology (e-government, e-governance etc.) refers to the application of information and communication technologies (ICT) in and around public administration (Homburg, 2008). In this paper, the term 'e-government' is used in very broad and general terms to refer to a public policy that tries to improve governmental processes and mechanisms of governance through the use of information and communication technologies (ICT), particularly the Internet and Internet access technologies (including mobile access). The term includes all the categories of electronic public services as usually differentiated in the literature - information- and transaction-based services for citizens and businesses, participation services for citizens, and also services to improve the internal processes of public administration (e-administration).

Regardless of the terminology used, e-government has become one of the most important elements of public sector reform, as it promises transparency, accountability, interaction with citizens, access to information, and good governance, including prevention of corruption (Špaček, 2012a). On the other hand, the spread of e-government provides a case of convergence in practice rather than in results (Wong \& Welch, 2004). E-government ideas have been extensively translated into practice around the world in the last decade. In EU member states today, we may distinguish the following general trends of e-government (Špaček, 2014; modified by the author):

- establishing new national portals or revising existing ones, sometimes by innovating their service delivery mechanisms (e.g., mobile IDs or enhanced personalization) or focusing on a specific field of communication between government and businesses/citizens (including e-procurement, e-invoicing, e-health, e-justice, and e-environment);

- deliberation about the role of mobile phones in public services delivery (m-government);

- cloud computing (delivering computing resources over the Internet)

- piloting e-participation/e-democracy projects (including e-voting, e-participation tools on national portals dedicated to legislation, experiments with e-consultations for identification of administrative burdens, and community building projects); deliberation about the use of the Semantic Web (Web 3.0) (Barassi \& Treré, 2012);

- promoting more internationally-recognized instruments for electronic identification (including the above-mentioned mobile IDs);

- searching for instruments to enhance effectiveness and efficiency (e.g., more complex managerial information systems, new institutional arrangements for e-government coordination and evaluation).

Although e-government policies have always been ambitious and many projects have been implemented, gaps continue to emerge between the revolutionary potential of ICT (reflected in the so-called e-government hype) and an evolutionary reality (Heeks, 2006). There is evidence that the problem of ICT failure is worse in the public sector than in the private sector, and cases of failure of public sector ICT projects are neither new nor rare (Garson, 2006). Critics usually point out that successful e-government must involve more than just using ICT and putting public services on the Internet. It implies re-engineering, reorganizing, and restructuring public organizations and shifting the focus on the citizen, creating customer-centred service provision (Makolm, 2006; Chen, 2010). As OECD stated repeatedly, e-government is more about government than about the "e": "Many e-government initiatives have been developed from a supply-side 'build and they will come' focus", merely overlaying existing organizational structures and processes rather than re-organizing them and there is still "a need to be able to measure potential demand, policy outcomes and quality improvements that can result from e-government initiatives" (OECD, 2003; see, also OECD, 2009). Also "[f]aults in adaptation to local 
conditions, culture, law, and implementation with follow through are real challenges" (Clift, 2004). Nguyen et al. (2014) claim that e-government implementation is far more about politics, humans, institutions and cultural norms (non-technical barriers) than about mere ICT issues.

This is clearly seen in the results of e-government policies as outlined, for instance, in available benchmarking reports. They still point out a gap between the availability of electronic services and their take-up. For example, a study of Capgemini et al. (2010) concluded that

"[T]he public sector is facing important challenges to rethink how public services can become more citizen-centric" (p. 13)... "Most eGovernment services still focus on delivering large scale administrative services designed to make existing government functions work more efficiently and effectively, such as tax and procurement systems, automation of registrations, permits and licenses, etc. These services are often existing services put online which are still basically silo-centric, top-down, with little service innovation, expensive, and with just as many failures as successes. In other words, their main focus remains first and foremost to serve the needs of government" (p. 74).

The latest benchmarking study for the European Commission (Tinholt et al. 2014a) points out that public services currently are not created and delivered seamlessly to citizens and businesses. And they are neither being used sufficiently, nor lead to satisfied users. Technology is the key driving force to enhance eGovernment performance, but at the moment it only shows its potential without being exploited. There is a gap between what is provided and how it is experienced. What is more, preferred personal contact and low awareness about existing e-government services represent the largest barriers preventing the use of online public services (Tinholt et al., 2014b), while it is being discussed to what extent other factors may increase the take-up of available services.

Factors of e-government services take-up are often drawn from diffusion of innovation (DOI) theories, the digital divide literature, or technology acceptance models (TAM). They include not only the potential/real users' ICT literacy, lack of trust, or intention to avoid personal interaction, but also contro (relative ability to exert control over the delivery of the service compared to another method), convenience (ability to receive the service how and when the individual wants to), cost, personalisation (ability to tailor service delivery more to the individual), and time (the time saved by obtaining the service electronically) (Gilbert \& Balestrini, 2004). DOI and TAM do not include factors which lie particularly on the side of government and public administration and are related to public implementation of e-government. In this respect, some studies also claim that progress in e-government has been hampered by legal, organizational and other obstacles. For example, the authors of the Breaking Barriers to eGovernment project discuss the role of leadership failures (during any stage in the initiation, implementation, promotion and ongoing support of development), financial inhibitors, poor coordination, workplace and organizational flexibility (to make necessary changes in public administration practices, processes and organizational structures), or poor technical design (interoperability issues) (Breaking Barriers to eGovernment, 2007). Garson (2006) discusses the role of complexity of ICT projects (which may become too large and complex), planning failure (poor business plans) and vision failure (unrealistic underlying assumptions, including the short-term horizons), or project management.

Similarities to factors which are internal to public administration can be found in literature on e-government maturity/sophistication models designed particularly for benchmarking purposes - see, for example, Siau and Long (2005) for a summary. Further sources include current benchmarking models used in UN e-government surveys (United Nations, 2014), or by Capgemini (Tinholt et al., 2014a). At higher levels, these models usually require intensive integration of various back offices, which has led to a growing demand for better e-government implementation, including coordination and evaluation. In response, for example, more centralization of e-government is currently visible in Europe, where central governments are clearly attempting to strengthen their coordination responsibilities. The coordination instruments they use in clude new regulation (on access to information, privacy protection, accessibility of e-services, standardization etc.), new central e-services for public authorities (like e-forms), and revision (reorganization) of existing coordination structures (Špaček, 2014).

The related discussion about the ICT productivity paradox has been already outlined in the introduction above. Even though evaluation is generally recognized as irreplaceable in each management process, more systematic theoretical and practical approaches to e-government evaluation began to appear more frequently as late as in the last decade and they are still evolving, taking into account knowledge from the service evaluation literature. Such approaches try to incorporate the requirements of a more rational (evidencebased, or at least evidence-driven - see, e.g., Lips \& Barlow, 2015) public management and a more rigorous ex-ante consideration of investments and effects (Špaček, 2013). 


\section{CURRENT APPROACH TO E-GOVERNMENT POLICY}

\section{AND IMPLEMENTATION - THE CZECH CASE}

Research on the effects of e-government implementation is rather scarce in the Czech Republic. The topic has not been given any systematic attention by the academia or by central authorities responsible for e-government coordination. However, the field has been developing (in terms of policy and real projects) at least for a decade (first e-gov strategies emerged in the late 1990s, first larger projects like the National Public Administration Portal at http://portal.gov. cz or submission of certain documents to social and tax administrations were launched soon thereafter).

Let us now take a look at the approach of the national government to egovernment policy, as it has been described in available literature, presented in official documents (including those focused on evaluation) or discussed in Czech media and specialized nongovernmental platforms (like eGov.cz). One can identify shortcomings particularly in the following areas of e-government policy:

- strategic framework;

- stability of political and executive leadership and policy coordination;

- evaluation of key national projects; data on the costs and effects of implementation;

- involvement of stakeholders in project design; awareness of existing services;

- public procurement

The following text discusses these apparent shortcomings further. The ambition of the author is not to handle all the shortcomings in an analytical way. The main aim of the present paper is rather to outline these gaps in e-government policy and its implementation.

\section{The e-government strategic framework}

E-government has been given extensive attention in the Central and Eastern European (CEE) region, and the Czech Republic is by no means an exception. However, in the region as well as in the country, e-government was not always an explicit part of the initial phases of public administration reforms. These initial phases of transformation and consolidation (see, e.g., Hesse, 1998) particularly emphasized the goals of initial democratization, laying the foundation of basic public administration structures (including de-concentration, decentralization and establishment of local and regional levels of government), and initial economic transformation (during which also the telecommunication policy, liberalization and regulatory mechanisms were given some attention). In contrast, the use of ICT in the public sector and in public administration was emphasized and given more systematic attention in the subsequent phase of modernization, starting in the late 1990s (Verheijen, 1998) and especially in the first years of the new millennium. Neither was e-government in EU candidate countries explicitly emphasized by the European Union in the early phase of the accession process; the European policy was shaped later, mainly in the period of 1999-2002, with the emergence of eEurope (and consequently eEurope+).

The first Czech national e-government strategies were approved by the government in 1999. That year is perceived as a critical juncture in Czech egovernment development (Smejkal, 2003; Špaček, 2012a), particularly thanks to the approval of the first State Information Policy ('SIP') and the subsequent Concept of Development of Public Administration Information Systems. Since that time, the aims of national e-government strategies ${ }^{2}$ have been more or less the same and central governments have been trying to address the problems of interoperability between various (Smejkal, 2003, speaks about 'thousands') public administration information systems established during the 1990s in central, regional and local administration. This heterogeneity raised questions about duplicity, about the accuracy and validity of data stored in information systems, and about the possibilities of overcoming the problems as many suppliers participated in creating solutions at various times.

Although e-government policy documents were approved frequently after 1999, none of the national strategies has been evaluated (see also below), updated or specified on a continuous (annual, or biannual etc.) and systematic basis. This was the case of strategies approved in the period of 2000-2004). Specific action plans and supplemented only the first formalized SIP strategy of 1999 as well as the Smart Administration Strategy of 2007 (but not the latest Strategic Framework of the Development of Public Administration in the Czech Republic for 2014-2020). Also, as with EU strategies, most of the strategies were rather broad, dealing with the development of an information society and treating e-government as one of its enablers. Although strategic documents rely show a high degree of interagency coordination, often the gen-

2 The following main national e-government strategies have been approved: SIP Action Plans of in 2000 and 2002, e-Czechia 2006 in 2004, the Smart Administration Strategy 2007-2015 in 2007, and the Development of Services for an Information Society and the E-government Implementation in a Territory stategies in 2008. Elements of e-governm and the E-governted in the Strategic istry of the Interior, 2014). 
eral e-government strategies did not integrate projects of strong central min istries such as the Ministry of Finance (e-taxes and e-treasury) or the Ministry of Social Affairs (social cards and e-forms). Together with the perceived low quality of e-government strategic documents, this has led to discussions on unhealthy departmentalism in designing (and subsequently implementing) egovernment policies. For instance, the Confederation of Industry of the Czech Republic (2012) perceived the draft Strategic Framework of the Development of Public Administration in the Czech Republic for 2014-2020 as an illustrative case of departmentalism and a mere attempt to ensure resources for priorities of the next programming period that were formulated without a broader public debate (the former Smart Administration Strategy was criticized similarly by the eStát initiative in 2007).

Czech e-government strategies also have not been evidence-based. Their texts usually do not integrate any evaluation of the status quo on which they would try to build their strategic priorities and objectives. What is more, they also often fail to consider the results of international benchmarking studies produced for the European Union or by the United Nations, or other evaluations that would enable at least some strategic analysis before a policy is decided. They even do not rely on data produced by the Czech Statistical Office (CSO), which annually evaluates selected aspects of readiness for e-govern ment (use of ICT by households, individuals and businesses) and ICT use in public administration. Although the CSO method does not cover extensively small municipalities with less than 500 inhabitants $(80 \%$ of the total number of 6200 municipalities) and focuses mainly on larger public authorities (major towns, regions and central authorities), some evaluation data have been available to the national e-government coordinator - the Ministry of the Interior (see also Section 3.3 below). This may lead to discussions about systematic biases in e-government functions due to parameters set incorrectly by the public administration.

It is also apparent in the available national e-government strategies that their strategic objectives often rely on highly general arguments like 'inefficient ICT use', 'non-existence of unified communication structure', 'no interconnection of individual registries', 'insufficient technical equipment', 'low PC literacy of civil servants', and 'non-existence of electronic communication in the state administration'. The two most recent national e-government strategies (the Smart Administration Strategy and the Strategic Framework of the Development of Public Administration in the Czech Republic for 2014-2020 were elaborated in parallel to documents clarifying the allocation of EU regional development funding (like the Integrated Operational Programme and the Human Resources and Employment Integrated Programme) which work with only highly general and particularly output-oriented indicators (such as the number of established basic registers, the volume of new fully electronic administrative agendas, and the number of established contact points), rather than with indicators such as time/money saved or user satisfaction. The lack of evidence on the status quo goes hand in hand with another general feature of national Czech e-government strategies (or documents supplementary to them) - they do not define their goals in a SMART (Specific, Measurable, Agreed, Realistic, and Trackable) to enable accountable implementation (including ex-post measurement/evaluation).

Finally, the lack of a clear vision has been criticized as one of the negative features of e-government implementation in the Czech Republic. This is further specified in Section 3.4.

\section{Stability of e-government leadership (and coordination) structures}

Referring to the e-government structures, one can clearly see a lack of stability of the political and administrative leadership and coordination of e-government implementation. The leadership and coordination structures for e-government became more stable particularly after 2006 when the Ministry of the Interior was given tasks of the abolished Ministry of Informatics (although it had originally been anticipated that e-government implementation would be entrusted to the Office of the Government with its interagency potential). Until then, the institutions established for e-government coordination had been struggling with being perceived as weak and inferior. This was further exacerbated by insufficient laws - for example, the first more stable coordination body - the State Information System Office ("ÚSIS") was not given specific responsibilities by the law which established it in 1996.

In 2000, the Act on Public Administration Information Systems (No. 365/2000 Coll.) established the Office for Public Information Systems ("ÚVIS"), which replaced the ÚSIS, and specified its responsibilities (including issuing standards and imposing sanctions). However, in communication with a number of strong ministries, the ÚVIS was again perceived as subordinate (Smejkal 2003), and it could not overcome departmentalism and the tendency of some central authorities (and their units) to act independently. There is no information on it ever imposing any sanctions.

In 2003, the ÚVIS was dissolved and its responsibilities delegated to the newly established Ministry of Informatics, which exercised its coordination tasks mainly through regulatory instruments (standards) and methodological guidelines. It also contributed to the launching of the national public administration portal (portal.gov.cz) in November 2004. Evaluation reports produced 
by the Ministry tackled especially the preconditions of e-government development (adoption of new legislation or policies, wider use of the Internet), rather than the outcomes of implemented projects (Špaček 2012a).

Considering the multiple areas of its existing responsibilities (including policing and fire prevention, civil registration, identity and travel documents archiving and e-government), the Ministry of the Interior has become a large multi-objective bureaucracy, a kind of super-ministry. However, the political leadership of the ministry was not stable, led by five different ministers in the period of 2007-2014. Czech media monitored the personnel changes, pointing out that between summer 2010, when a new right-wing government was appointed, and spring 2011, the Deputy Minister for Informatics changed seven times (eGov.cz, 2012a and 2012d). Within the 2012-2013 term of office, the deputy responsible for public administration and e-government changed three times, and there were also changes on the ministerial post in 2011, 2013 and 2014 , partly caused by political crises. The frequent changes in political leadership have been criticized by the European Commission, prompting discussions and restrictive precautions in Integrated Operational Programme funding. Such changes lead to situations in which people that were to be held accountable for previous mismanagement often were no longer in office, as pointed out by Veselý (2013).

The current Civil Service Act applicable since the beginning of 2015 assigns to the Ministry extensive coordination roles in the area of civil service, which may impact its functioning in other areas, including e-government. Such impacts can be partly indicated by the scarcity of information on Czech public administration reform, its goals and effects, as published on the Ministry website at present time (for example, a previous section that contained a relatively large amount of information on quality management in public administration was recently reduced to a brief introduction of the current strategic framework for the period of 2014-2020).

\section{National e-government evaluation}

Although e-government ideas have been reflected in various projects of the central government as well as local governments, their results have not been subject to sufficient evaluation by central authorities. There is only scarce information on the effects of e-government implementation. Its costs can be only estimated indirectly and partially on the basis of information on public procurement and implementation of the resulting contracts between public authorities and their suppliers. The absence of ex-ante impact assessment further hinders the attempts to compare what was expected and what was actually de- livered. Scarce evaluation (together with issues of public procurement as outlined below) also raises questions about the transparency of e-government implementation

Publicly available information about the planning, implementation and outcomes of key Czech national e-government projects (particularly the Czech POINTs, Data Boxes and basic registers) is still scarce. However, for example, even the Smart Administration Strategy of 2007 anticipated that continuous monitoring of the quality of public administration would be implemented. Whenever information on e-government evaluation exists, it is not analytical in nature. Existing national evaluation studies are rather supply-centred, focusing on the quantity and quality of available e-government services, rather than on their take-up and user satisfaction.

The central coordinator of the projects, the Ministry of the Interior, has not been systematically evaluating the demand aspects of e-government services. Since 2007, it has not published any summary information on the evaluation of e-government, and its evaluation effort has been neither regular nor ad hoc. As summarized by Špaček (2013), the information published thus far does not include a comprehensive evaluation of the most heavily promoted national projects (Czech POINTs, Data Boxes and basic registers). Although some projects were launched years ago, available evaluations refer only to total numbers (of extracts generated through Czech POINTs, messages sent through Data Boxes, activities conducted in basic registers, etc.). The former Group for Smart Administration Coordination has only published a list of projects proposed for EU funding, without commenting on their prioritization or cost-benefit characteristics. Annual reports on the status quo of Smart Administration (Ministerstvo vnitra, 2011, 2012b) were very superficial and limited to information such as that most of the planned activities had been carried out or that calls for project proposals had been launched. The most recent national e-government evaluation still focuses mainly on the quantifiable aspects (such as the number of existing e-services, the number of visits, the total money spent on education), rather than on user satisfaction or other outcomes (Špaček, 2014).

No study published so far has focused on citizens' perceptions of the uses and benefits of e-government projects. The Ministry of the Interior usually only emphasizes the growing outputs (e.g., number of Czech POINT providers, number and structure of services used by customers, number of data messages sent through Data Boxes). With regards to the key project of basic registers (fully launched in June 2012), information published by institutions responsible (particularly the Ministry of the Interior and the Office for the Administration of Basic Registers) has only tackled the project's implementation in a superficial and partial way. Although a study titled "Impacts of the launching of ba- 
sic registers on territorial self-governments" was published and the Ministry of the Interior presented a pilot version of basic registers and a roadmap of effects during the national e-government conference ("ISSS") in April 2012, it is still not clear in what phase the project of individual basic registers currently is and some commentators are sceptical about the roadmap (e.g., Peterka, 2012, even perceives the presentation during the conference as propaganda, another commentator as "theatre" performance).

Furthermore, the Ministry of the Interior has not systematically coped with the evaluation of ICT in regional and local governments. Some legal duties with regard to e-government exist only on paper, e.g. in the areas of freedom of information (particularly Act No. 106/1999 Coll.) and long-term management of public administration information systems (Act No. 365/2000 Coll.). As another example, public authorities are obliged to draw up information strategies addressing the following overall questions with regard to quality management and security: "Where are we now?", "Where do we want to get to and why?", and "How do we get there from here?" (including the necessary resources) They have to publish the strategy, implement it and evaluate whether and to what degree it has been fulfilled. The strategies should have been ready by 1 January 2009. Available research which focused on the content of the information strategies of larger Czech self-governments (statutory cities and regions) indicates that the strategies do not define their goals in the SMART way (this could ensure better feasibility, accountability and monitoring transparency). Also evaluation "metrics" appear very rarely in the strategies. The strategies developed by consulting firms for different authorities may be largely identical and differ only marginally, in parts identifying the information systems operated by the authority (information systems of public administration - ISPA operational information systems linked to ISPA and other operational IS). It remains unclear how and to what degree such similar strategies are adapted to the practice of particular organizations. The strategies are usually too general and do not specify the status quo, the costs of particular solutions or particular quality and security management schedules. (Špaček, 2012b).

The Czech Statistical Office (CSO) has remained the only central authority publishing some information on inter-sectoral e-government practices and measuring several aspects of e-service delivery. Still, the CSO cannot supply the national e-government coordinator with more in-depth research data for a more evidence-based design of e-government policy. Its measurement of ICT use in public administration rests on two surveys. In the first survey's meth odology, the supply side prevails, although it is usually touched upon very broadly. The survey may not be able to tackle one specific feature of the Czech administrative system - the large number of municipalities. Distributed to al- most 6,700 public authorities, its questionnaire is divided into two parts. The first part is addressed to all public authorities and encompasses access to the Internet, the security measurements used, the web pages and services provided for citizens. The second part, which focuses on human resources and electronic data interchange, is not addressed to the almost 5,000 municipalities with fewer than 1000 inhabitants. The second survey is web-based and has been carried out by the CSO since 2004. It covers exclusively the 205 municipalities with extended responsibilities (obce s rozšířenou pưsobností, MER), although the reporting obligation is prescribed to almost all municipalities, 25 central authorities and 14 executive bodies of Czech regions. The scope of CSO surveys of ICT use in public administration is much narrower in comparison to its surveys in the business sector, although the methodology of the latter may serve as an inspiration for further modification and elaboration of the former.

CSO measurements still do not deal with some key national projects such as the Data Boxes. Its questionnaires addressed to public authorities and posted on the websites of selected public authorities cover neither the incentives to use e-services nor aspects of user satisfaction regarding the key national projects. The structure of electronic services which are used by users is covered in more depth by the latest survey among businesses. Similarly to the existing methodology of the Eurostat, CSO surveys among individuals/households and businesses are not linked to the list of 20 services that have been benchmarked for the European Commission by Capgemini. The results are also not up-to-date. In its latest publication on ICT use in public administration, the CSO works with data from 2011.

\section{Stakeholder involvement in project design, take-up and public awareness}

Various actors (other central authorities, local and regional governments and their associations, mass media etc.) have criticized central government for a strictly top-down design of various public policies and e-government projects, for their implementation and (insufficient) evaluation.

This is also the case of a recent reorganization of social welfare administration which was effected in January 2012. While the provision of social security benefits was transferred from MERs to the newly organized Labour Office, the former remained responsible for social work. This change had not been communicated sufficiently and countless municipalities have criticized the speed of the reform, its insufficient preparation and the ensuing chaos in personnel. The reform was accompanied by a new ICT solution which did not work properly for almost a year (blackouts, data losses, slowness. In January 
2012, some people who were entitled to social benefits did not receive them (Chum, 2013). In April 2012, the system was still not functioning properly, was unstable and lacked some important functions, according to employees of labour offices (who also called on the Minister of Labour and Social Affairs to resign). A number of businesses had to work on the solution, the Ministry of Labour and Social Affairs did not launch a public tender for it, and some media criticized the extortionate price and lack of transparency - insufficient information provided by the Ministry on who was in charge of the solution etc The tender is now being investigated by the Office for the Protection of Competition.

Referring to the functions of basic registers, at the beginning of 2013 the president of the Union of Towns and Municipalities pointed out that, for example, the Register of Inhabitants did not offer information on specific territories of interest to municipalities (Křížová, 2013):

"How do you want to provide school and pre-school education if you do not know how many children you will have in the territory or how old they will $b e$ ? We need such a survey not only for our territory. It would be beneficial to include Municipalities with Extended Responsibilities to find out how many children there are in a neighbouring village and where they commute to schools. Such information was quite commonly exchanged in the past but today it is no longer possible."

The Register of Vehicles represents a similar case. In 2012, a new version of the Register was launched and the managing responsibility transferred from the Ministry of the Interior to the Ministry of Transport. The very launch was accompanied by a breakdown and long-term blackout of the Register. In mid-August, full operation was expected to resume as late as October; people were queuing at the Register's offices because the new system was far slower, and the officials were working simultaneously in the old and the new system. The citizens relieved themselves of their legal obligations to register their vehicles and resorted to claiming damages. Representatives of municipalities pointed out that most of the public outrage went to them. Still in 2013, for example, the President of the Association of Secretaries of Municipal Offices argued: "Only half a year after, the Ministry admitted that the system was not yet fully functional. Strictly speaking, staff changes in the top management were useless. Still by far not everything is as expected and the system is less satisfying than the previous one" (Chum, 2013). In July 2013, some officials criticized the reg ister for the absence of a number of details, which had to be entered manually (Česká televize, 2013).
Some criticized the Ministry of the Interior for having no clear vision on the future potential of existing projects like the National Public Administration Portal which had been developing since the autumn of 2003 and was replaced in February 2012. Representatives of the Ministry pointed out that the Ministry administered various information systems with similar functionalities, namely the Data Box IS and the transactional part of the National Public Administration Portal. The Ministry proposed merging these systems under the Data Box Portal (established in June 2011). This was done without any major communication with users or authorities like the Ministry of Labour and Social Affairs, which had been providing services through the portal and had to quickly adapt and prepare alternative e-submission instruments (Peterka, 2011). In October 2011, the homepage of the Data Box Portal informed that it would become a portal from which users could access intelligent e-forms as well as their Data Boxes and that the Ministry of the Interior had been negotiating with individual authorities in order to provide users with such e-forms. In late March 2012 the design of the National Public Administration Portal changed and its former transactional part was removed. Still in December 2014 only the information part remained, one could only access his/her Data Box and the Data Box Portal offered no e-forms. In fact, there was no central one-stop shop) to enhance access to electronic public services.

The eIDs project represents another example of unclear and insufficiently deliberated, communicated and coordinated Czech e-government project. During the 2009 ISSS conference, the Ministry of the Interior announced that it would start issuing eIDs in July 2010. In July 2011, the Ministry talked about a postponement till 2014 due to funding problems. In October 2011, the Ministry issued a decree that foresaw the issuing of e-IDs from the beginning of 2012 The launch was broadly criticized by affected municipalities. Old IDs had been issued by all municipalities with registry offices, including smaller ones. Since 2012 new eIDs were only issued only by MERs. Representatives of MERs crit icized the speed of the change, the lack of additional funding (although the change required additional technical equipment) as well as the deterioration of access (Veřejná správa, 2011). Any citizen can pay a fee to have his/her e-signature activated with the new eID. In practice, however, this is still of no major use (e.g., for e-submissions or Data Boxes). That is probably why the Ministry still provides rather restricted information on eIDs.

Although the Data Box project was presented with a large amount of enthusiasm by the Ministry of the Interior, their role in further development of Czech e-government may be hindered by activities of other stakeholders. For instance, the Ministry of Finance recently proposed that tax returns could no longer be submitted via Data Boxes (see, e.g., eGov.cz, 2015). Insufficient com- 
munication between key actors of e-government development may also be reflected in legislation (for example, citizens are required to provide municipal authorities with their photo in order to apply for a new driving licence, even if their photo may already be recorded in basic registers if they had applied for a new personal ID or passport before). This situation calls for improved coordination and a higher level of inclusion in the phase of preparation of strategic documents, new laws or e-government projects. Such improved policy planning might also eliminate the failure of public administration to define the objectives clearly and with a focus on users of e-government services.

In 2009, i.e. one year after the full launch of the Czech POINT project, Šimoník, Pojer \& Svoboda pointed out that more than half of the Czech population were aware of existence of Czech POINTs, but only 28\% knew where they could visit the closest terminal and $88 \%$ had never used Czech POINT services. In 2010, a Czech Statistical Office survey showed that almost 1/3 of individuals older than 16 years did not know the project and that $57 \%$ of individuals were aware of the project, but had not used it. In 2012, a survey showed that stil $30 \%$ of population did not know the project and that $51 \%$ of individuals were aware of the project, but had not used it. Only $10 \%$ of individuals had used Czech POINT services at least once. According to a 2014 report, only $26 \%$ of individuals older than 16 years used the Internet in their communication with public administration to find information, $12 \%$ to download forms and $7 \%$ to fill in forms online.

In the case of the Data Box project, the CSO focuses only on use by businesses, not by citizens or public authorities (for which more duties to communicate via the instrument exist) (ČSÚ 2010, 2012, 2014). For example, Smejkal (2011) points out that civil servants are not willing to use the Data Box IS to send a message to a person who evidently has a Data Box established and activated (although the law requires so), to accept a data message which was sent without using the e-signature (although the use of e-signature in communication with public authorities is not required by the law), or they require messages/documents in paper form, rejecting messages sent through the Data Box.

\section{Public tenders for e-government projects}

Many questions have been raised in relation to the Czech practice of public procurement in the field of e-government. As eGov.cz pointed out, only one bidder participated in more than $70 \%$ of e-government public tenders (accounting for more than CZK 5 billion) in 2011. The winning bidders usually reserved copyright and exclusive rights to maintain and develop the information systems. This may be critical given that only 10 organisations won more than
$80 \%$ of all the tenders (eGov.cz, 2012c). Some resulting problems are outlined below.

For instance, Smejkal (2011) criticized an immense delay in the establishment of basic registers due to tendering problems. The tenders for the Register of Inhabitants and the Register of Rights and Responsibilities were particularly problematic. In March 2010 the Ministry of the Interior closed the tender with Accenture as the winner. However, two other bidders (ICZ and Asseco) appealed against the results, criticizing the process as well as the price proposed by the winner, which was perceived as unrealistic and extraordinarily low in comparison to other bids. The Office for the Protection of Competition repealed the decision of the Ministry and returned the tender to the phase of winner selection.

Also criticized have been the health registries which were supposed to be integrated in the eHealth central solution,, because the Departmental Health Information System Coordination Centre (directed by the Ministry of Health) extended the deadline for bid submission just a few hours before it expired (eGov, 2012e). Practice of the new Register of Vehicles represents another example criticized. The company responsible for its development won the public tender without allowing other companies to take part, although it had no sufficient experience with such large projects.

Recent critique focused on the establishment of so-called data centres with support from European funds. In May 2015 the Office for the Protection of Competition criticized that the establishment, development and use of data centres was rather uncoordinated and without specific rules. The Office audited the development of a data centre for the STC (Státní tiskárna cenin) which was coordinated by the Ministry of Finance. A company that participated in the preparation of tender documentation and parameters was subsequently awarded a tender and became one of the main suppliers because it offered a solution that matched the public tender parameters perfectly. Following these findings, the Office recommended to change the Act on Public Procurement in order to guarantee fair access to information for all potential competitors and to reduce the advantages of those who participate in tender preparation (NKÚ, 2015)

\section{CONCLUSIONS}

The present paper sums up information about e-government implementation and coordination in the Czech Republic in order to describe the features of national coordination of e-government policy. On one hand, the paper clearly 
shows that Czech central authorities have not been passive in terms of e-government rhetoric. Since the late 1990s various ambitious e-government strategies have been approved. On the other hand, with regard to their approach to the design and implementation of e-government policy, the paper outlines and discusses a number of shortcomings which call for further research into the non-technical barriers of e-government implementation.

Although the data are not conclusive, the account of the shortcomings, or even dysfunctions of e-government implementation suggests two main causes. First, a number of systematic biases may stem from the incorrectly set parameters by the public administration. This was illustrated by shortcomings in the national e-government strategic framework and deficiencies of evaluation methodologies and practices available at the national level (with regard to key national e-government projects). Although, for example, the Smart Administration Strategy of 2007 anticipated continuous monitoring and evaluation of the quality of public services, efforts to evaluate e-government are hardly visible they are rather supply-centred and they do not cope with real effects of e-government implementation specifically. The existing approach to e-government implementation (and evaluation) undermines the legitimacy and transparency of the effort and also raises questions about the accountability of the centra authorities responsible for its coordination. Available evaluation studies in dicate that e-government development is hardly evidence-based. Rather it is driven by opportunities to use the EU funding, which may cause additional in coherence. Practices, institutional structures and funding mechanisms in other areas such as social services or regional development indicate that such characteristics can be seen across the Czech administrative system.

Furthermore, coordinated development of e-government may be hindered by other existing features such as unstable political and administrative leadership. These shortcomings are also reflected in the low involvement of stakeholders in project design and evaluation, and supplemented by low levels of awareness and take-up of existing services. Frequent changes at the national level of e-government implementation (and coordination) also limit the top civil servants in holding their pivotal position in enhancing interdepartmental coordination (Hansen, Steen \& de Jong, 2013).

The latter relates to the second cause of e-government failures, which concerns the actors who implement and maintain the e-government systems. The paper has outlined examples of departmentalism in e-government development, raising questions about a unified vision of e-government development, about policy coordination and also about the efficiency of both existing and future e-government solutions. Departmentalism may be also reflected in public procurement. These practices may result in tenders that are formally and pro- cedurally correct yet not workable for a more integrated e-government development.

Although there is not much data to support the conclusion, the available data indicates that the local and regional governments' criticism of central government intensifies with growing responsibilities and increasing complexity of projects (as implementation problems caused by insufficient preparation become more obvious). Municipalities relatively well accepted the Czech POINT project of one-stop shops which was implemented incrementally, brought smoother horizontal (between central authorities) as well as vertical (between the centre and regional and municipal governments) administrative cooperation, and increased cooperation between central government and other stakeholders. Statements that it is too early for some projects (like the basic registers) to be evaluated are not sustainable. The practice clearly reveals that their preparation by central authorities should have been accompanied and bolstered by more extensive communication within the public administration

\section{REFERENCES}

Barassi, V., \& Treré, E. (2012). Does Web 3.0 come after Web 2.0? Deconstructing theoretical assumptions through practice. New media \& society, 14(8), 1269-1285.

Breaking Barriers to eGovernment (2007). Solutions for eGovernment (Deliverable 3). Retrieved from http://www.oii.ox.ac.uk/research/projects/egovbarriers/deliverables/ solutions_report/Solutions_for_eGovernment.pdf.

Capgemini et al. (2010). Digitizing Public Services in Europe: Putting ambition into action Retrieved from http://www.epractice.eu/files/Digitizing\%20Public\%20Services\%20 in\%20Europe\%20Putting\%20ambition\%20into\%20action\%20-\%209th\%20 Benchmark\%20Measurement\%20-\%20December\%202010.pdf.

Chum, J. (2013). Připadali jsme si skoro jako v Kocourkově [We thought like being in the Crazy Town](interview with the president of Association of secretaries of municipal offices). Veřejná správa, 1, 10-11.

Clift, S. L. (2004). E-government and democracy: Representation and citizen engagement in the information age. Retrieved from http://www.publicus.net/articles/ cliftegovdemocracy.pdf.

Česká televize (2013). Ani po roce registr vozidel nefunguje bezchybně [Even after one year the register of vehicles does not function properly].

Confederation of Industry of the Czech Republic (2012). Pripominky SP ČR ke Strategickému rámci rozvoje veřejné správy a e-governmentu 2014+[Comments of the Confederation of Industry of the Czech Republic to the Strategic framework of development of public administration and e-government for 2014+]. Retrieved from http://old.spcr.cz/en/ statesment/pripominky-sp-cr-ke-strategickemu-ramci-rozvoje-verejne-spravy-a-egovernmentu-2014.

Čsú (2010). Informačni společnost v čislech 2010 [Information society in numbers 2010]. Retrieved from http://www.czso.cz/csu/2010edicniplan.nsf/t/ F20039D56A/\$File/970510.pdf. 
ČSÚ (2012). Informační společnost v číslech 2012 [Information society in numbers 2012]. Retrieved from http://www.czso.cz/csu/2010edicniplan.nsf/t/ F20039D56A/\$File/970510.pdf.

Čsú (2014). Informační společnost $v$ číslech 2014 [Information society in numbers 2014]. Retrieved from http://www.czso.cz/csu/2014edicniplan.nsf/t/ AD0026B96A/\$File/061004-14.pdf.

eGov.cz (2012a). Časté personální obměny na vnitru mohou ohrozit čerpání eurodotací [Frequent personal changes at the Ministrz of the Interior may jeopardize the use of Eurosubsidies]. Retrieved from http://www.egov.cz/index.php?option=com content\&view=article\&id=344:aste-personalni-obmny-na-vnitru-mohou-ohroziterpani-eurodotaci-\&catid=1:egovernment\&ltemid $=3$.

eGov.cz. (2012c). eGovernment $v$ roce 2011-5 miliard zadáno $v$ tendrech s jediným uchazečem [eGovernment in 2011-5 milliard given to tenders with ounly one bidder]. Retrieved from http://www.egov.cz/index.php?option=com_content\&view=article\&id 390:egovernment-v-roce-2011-5-miliard-zadano-v-tendrech-s-jedinym-uchazeem\&c atid $=2$ :komentaraapostrehy $\&$ temid $=4$.

eGov.cz (2012d). Jak ovlivní nové organizační změny na vnitru další rozvoj eGovernmentu? [How will new organizational changes at the Ministry of the Interior change further eGovernment development]. Retrieved from http://www.egov.cz/index. php?option=com_content\&view=article\&id=374:jak-ovlivni-nove-organizani-zmny-navnitru-dali-rozvoj-egovernmentu\&catid=2:komentaraapostrehy\&ltemid=4.

eGov.cz (2012e). ÚOHS šetři podivný tendr na zdravotní registry [Office for the Protection of Competition investigates a tender on health registers]. Retrieved from http://www.egov. cz/index.php?option=com_content\&view=article\&id=405:uohs-eti-podivny-tendr-nazakladni-registry\&catid=7:ostatni-ejustice-el-podpis\&ltemid=3.

eStát.cz (2008). Smart Administration - reforma nebo jen pozlátko pro evropské úredniky? [Smart Administration - reform or a mere glitz for European civil servants?]. Retrieved from http://www.estat.cz/smart-administration-reforma-nebo-jen-pozlatko-proevropske-uredniky2.html.

European Commission (2010a). A Digital Agenda for Europe. Retrieved from http://eur-lex. europa.eu/LexUriServ/LexUriServ.do?uri=COM:2010:0245:FIN:EN:PDF.

European Commission (2010b). The European eGovernment Action Plan 2011-2015. Retrieved from http://ec.europa.eu/information_society/activities/egovernment/ action_plan_2011_2015/docs/action_plan_en_act_part1_v2.pdf.

Garson, G. D. (2006). Public information technology and e-governance: Managing the virtual state. Carlow: Jones \& Bartlett Learning.

Gilbert, D., Balestrini, P., \& Littleboy, D. (2004). Barriers and benefits in the adoption of -government. International Journal of Public Sector Management, 17(4), 286-301.

Hansen, M. B., Steen, T., \& de Jong, M. (2013). New Public Management, Public Service Bargains and the challenges of interdepartmental coordination: a comparative analysis of top civil servants in state administration. International Review of Administrative Sciences, 79(1), 29-48.

Heeks, R. (2005). Implementing and managing eGovernment: an international text. Thousand Oaks: Sage.
Hesse, J. J. (1998). Rebuilding the state: Administrative reform in Central and Eastern Europe. Preparing Public Administration for the European Administrative Space, Sigma Papers, (23), 168-79.

Homburg, V. (2008). Understanding e-government: Information systems in public administration. New York: Routledge.

Chen, Y. C. (2010). Citizen-centric e-government services: Understanding integrated citizen service information systems. Social Science Computer Review, 28(4), 427-442.

Křížová, L. (2013). Státní orgány by měly zákony vykládat jasně [State authorities should interprete law clearly] (interview with the President of Union of Towns and Municipalities of the Czech Republic). Veřejná správa, 1, 6-8.

Lips, M., \& Barlow, L. (2015). Reconceptualising Evidence-Based Policy in the Age of Big Data: Implications for Public Policy Practice and Scholarship. Paper for IRSPM Panel G107'Managing the digital future of the public sector: transforming public management through e-Government'?

Makolm, J. (2006, January). A holistic reference framework for e-Government: the practical proof of a scientific concept. In System Sciences, 2006. HICSS'06. Proceedings of the 39th Annual Hawaii International Conference on (Vol. 4, pp. 77a-77a). IEEE.

Nguyen, T. Q., Teicher, J., Van Gramberg, B., \& Tran, H. (2014). Non-technical barriers in e-government implementation: the case of e-Customs in Vietnam. IRSPM 2014 onference.

NKÚ. (2015). Informace z kontrolní akce NKÚ č. 14/20: Peněžní prostředky státu vynakládané na výstavbu, provoz a využívání služeb datových center [Information on control activities of the Supreme Audit Office - Money invested in establishment, maintenance and use of data centers services]. Retrieved from: http://www.nku.cz/ assets/media/informace-14-20.pdf.

OECD (2003). e-Government Studies - The e-Government Imperative. Paris: OECD.

OECD (2009). Rethinking e-Government Services: User-Centred Approach. Paris: OECD.

Pina, V., Torres, L., \& Royo, S. (2010). Is e-government promoting convergence towards more accountable local governments?. International Public Management Journal, 13(4), $350-380$

Peterka, J. (2011). Portálová rošáda [Portal castling]. Retrieved from http://www.lupa.cz/ clanky/portalova-rosada.

Peterka, J. (2012). Základní registry prý budou v termínu [Basic registers are to function in time]]. Retrieved from http://www.lupa.cz/clanky/zakladni-registry-pry-budou-vterminu.

Siau, K., \& Long, Y. (2005). Synthesizing e-government stage models-a meta-synthesis based on meta-ethnography approach. Industrial Management \& Data Systems, 105(4), 443-458.

Smejkal, V. (2003). Informační systémy veřejné správy ČR [Information systems of public administration in the Czech Republic]. Praha: VŠE.

Smejkal, V. (2011). Aktuálni problémy elektronické komunikace $v$ ČR [Current problems of electronic communication in the Czech Republic]. Konference Datové schránky - rok druhý. Retrieved from http://www.dataschranky.cz/2011/download/prezentace/ smejkal.pdf. 
Šimoník, P., Pojer, P., \& Svoboda, J. (2009). Pilíre projektů eGovernment očima občana zákazníka veřejné správy [Pillars of eGovernment project in the eyes of a citizen - a customer of public administration]. ISSS 2009, 249-253.

Špaček, D. (2012a). eGovernment: cile, trendy a prístupy k jeho hodnocení [eGovernment: goals, trends and approaches to evaluation]. Praha: C. H. Beck.

Špaček, D. (2012b). Information Strategies of Czech Statutory Cities and Regions: Critical Remarks. Knowledge Management: An International Journal, 3, 31-46.

Špaček, D. National approach to e-government evaluation - Challenges of accountable (e)government in the Czech Republic. Modern Approaches, Metrics and Indicators for Monitoring and Evaluating Public Policies. 265-300.

Špaček, D. (2014). Coordination of and through E-Government: The Case of the Czech Republic. NISPAcee Journal of Public Administration and Policy, VII(1), 83-107.

Tinholt, D. et al. (2014a). Delivering the European Advantage? (Background Report). Retrieved from http://www.capgemini.com/resource-file-access/resource/pdf/ background_report_20-05_final_for_ec_0.pdf.

Tinholt, D. et al. (2014b). Delivering the European Advantage? (Insight Report). Retrieved from http://ec.europa.eu/information_society/newsroom/cf/dae/document.cfm?doc_ id $=5811$.

Veselý, A. (2013). Accountability in Central and Eastern Europe: concept and reality. International Review of Administrative Sciences, 79(2), 310-330.

Veřejná správa (2011). Elektronický kabát pro občanské průkazy [Electronic coat for IDs]. Veřejná správa, 22, 10-11.

Willcocks, L., \& Lester, S. (1996). Beyond the IT productivity paradox. European Management Journal, 14(3), 279-290.

Wong, W., \& Welch, E. (2004). Does e-government promote accountability? A comparative analysis of website openness and government accountability. Governance, 17(2), $275-297$ 